\title{
Quality characteristics of Platycodon grandiflorum depending on steaming treatment
}

\author{
Jung-Min Kim ${ }^{1}$, Kwang-Sup Youn ${ }^{1,2 *}$ \\ ${ }^{1}$ Department of Food Science and Technology, Daegu Catholic University, Gyeongsan 38430, Korea \\ ${ }^{2}$ Institute of Food Science and Technology, Daegu Catholic University, Gyeongsan 38430, Korea
}

\section{증숙처리에 따른 도라지의 품질 특성

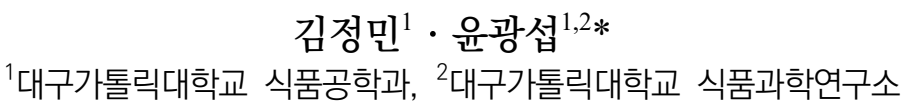

Abstract

\begin{abstract}
This study aimed to determine the quality characteristics of Platycodon grandiflorum depending on the steaming method. Platycodon grandiflorum was steamed at $95^{\circ} \mathrm{C}$ for $3 \mathrm{~h}$, and autoclave steamed for up to three times (AS1-3) at $121^{\circ} \mathrm{C}$ for $15 \mathrm{~min}$. The $L^{*}$ and $b^{*}$ color values were tended to decrease between AS1 and AS3, whreas the $a^{*}$ value tended to increase. The browning index increased with steaming, and tended to increase rapidly after AS2. The total sugar and reducing sugar contents were significantly higher after AS3. Crude saponin contents were in the order of AS3 $>$ AS2 $>$ Steaming $>$ AS1 $>$ Control, and were higher than that of the control in all steamed groups. Platycodin complex content was the highest in the control, and was judged to be decomposed by pressure and steaming treatment. Total polyphenol and flavonoid contents were significantly higher after pressurized steaming than in the others and tended to increase with repeated steaming. Pressurized steaming increased the ability to scavenge DPPH and ABTS radicals and significantly increased after AS2. Therefore, pressurized steaming can shorten the process time and improve the antioxidant effects of Platycodon grandiflorum.
\end{abstract}

Key words : Platycodon grandiflorum, steaming process, pressurized steaming, platycodin

\section{서 론}

도라지(Platycodon grandiflorum)는 초롱꽃과(Campanulaceae)의 여러해살이 풀로 7-8월에 종 모양의 흰색 또는 자주 색 꽃을 피우며, 뿌리를 식재나 약재로 이용한다(Yoo 등, 2010). 도라지 뿌리는 전통적으로 나물, 도라지 즙, 도라지 차, 도라지 분말 죽, 도라지 정과 등에 이용되고 있다. 동의보 감에 의하면 도라지는 호흡기계 질환에 효과가 높다고 기록 되어 있으며, 최근 항염증 작용, 중추신경억제 작용, 혈압 강 하 작용, 항choline 효능성 작용, 용혈 작용 등의 다양한 약리
효과가 검증되었다(Park 등, 2009). 도라지 추출물의 면역력 증진, 항암 및 항균 효과 등의 기능성 연구를 비롯하여 건조 방법, 저장방법 및 저장기간에 따른 도라지 뿌리 중 platycodin $\mathrm{D}$, polygalacin $\mathrm{D}$ 및 deapioplatycodin $\mathrm{D}$ 등의 platycoside류 사포닌 함량의 변화에 대한 연구도 보고되어 있다(Kim과 Jeong, 2015; Lee 등, 2014). 다양한 생리활성 성분을 함유하 고 있는 도라지는 천연약물 및 건강 보조식품으로 이용될 뿐 만 아니라, 도라지 식혜(Jeong과 $\mathrm{Yu}, 2013)$, 도라지 설기떡 (Hwang과 Kim, 2007), 도라지 양갱(Park 등, 2009), 도라지 쿠키(Jeong 등, 2013) 및 도라지 당과 등 다양한 가공식품에

*Corresponding author. E-mail : ksyoun@cu.ac.kr, Phone : +82-53-850-3209, Fax : +82-53-850-3209

Received 14 August 2020; Revised 22 September 2020; Accepted 23 September 2020.

Copyright (c) The Korean Society of Food Preservation.

This is an Open Access article distributed under the terms of the Creative Commons Attribution Non-Commercial License (http://creativecommons.org/licenses/by-nc/4.0) which permits unrestricted non-commercial use, distribution, and reproduction in any medium, provided the original work is properly cited. 
도 활용되고 있다.

그러나 도라지의 다양한 효능에도 불구하고, 자체의 강한 쓴맛으로 인하여 소비자 기호도가 나뉘기 때문에 껍질을 탈 피하여 찬물로 쓴맛을 우려내어 제거하거나 익히는 등 조리 과정을 거쳐 보다 많은 사람들이 섭취할 수 있도록 하고 있 다. 아직까지 도라지의 쓴맛 성분은 명확히 밝혀지지 않았으 나, platycodin 등의 사포닌류인 것으로 알려져 있는데(Jeong 과 $\mathrm{Yu}, 2013)$, 이들 성분을 제거 또는 낮추기 위한 생도라지 를 증숙 및 발효 과정은 사포닌을 가수분해시켜 도라지의 맛 과 냄새 등 기호도를 상승시킬 뿐만 아니라, 기능성도 높게 한다는 연구 결과가 보고되어 있다(Park, 2011).

증숙 공정은 한방에서 쪄서 익히는 것을 말하며, 증기를 이용해 열처리를 하여 세포의 구성 성분들의 변화를 유도하 여 새로운 화합물을 만들어 내거나, 세포 조직을 파괴하여 유 용성분 용출을 극대화하는 공정이다(Lee 등, 1995). 인삼 가 공공정에서 많이 사용되어 홍삼 또는 흑삼을 만들 때에 사용 하는 방법으로, 현재 그 영역이 확대 적용되어 흑마늘, 흑더 덕, 흑양파, 흑도라지 등이 개발 및 시판되고 있다. 홍삼의 경 우, 증숙과정 중에 형성된 갈색 물질이 풍미, 색상개선 등의 효과뿐만 아니라, 항산화 활성 및 기능성분으로서의 효과가 입증되었다(Lee 등, 2013). 하지만 기존의 증숙공정은 시간 이 많이 소요되는 단점이 있어 이를 보완하기 위하여 고압 및 저온고압 공정을 이용해 단시간에 최소 처리하여 식품을 생산하는 방법으로 식품의 영양성분, 맛, 향기, 비타민 함량 등의 손실을 줄일 수 있으나 과한 처리 시 탄화가 일어나 활성 성분이 파괴되는 단점이 있다(Hong 등, 2007; Jin 등, 2009).

따라서 본 연구는 증숙 처리에 따른 도라지의 품질특성을 조사함으로써 도라지의 가공 활용성 및 기능성 증진을 위한 목 적으로 증숙도라지 제조를 실시하였으며, 기존의 증숙공정과 가압증숙공정을 비교하여 이화학적 특성, 항산화 활성을 비교 분석하여 도라지를 이용한 가공제품 개발 및 기능성 식품소재 로 활용할 수 있는 산업적 기초자료로 제시하고자 한다.

\section{재료 및 방법}

\section{재료}

도라지는 전남 장흥군 소재의 장수촌 도라지영농조합에서 2019년 12월 수확한 6년근 약도라지(일반 도라지)를 구입하 여 길이 $20 \mathrm{~cm}$ 이상을 선별한 후, $4^{\circ} \mathrm{C}$ 에서 냉장 보관하면서 사용하였으며, 증숙도라지 제조 시 수세하여 이물질 제거 및 박피 후 $4 \mathrm{~mm}$ 의 두께로 절단하여 사용하였다. 실험에 사용 된 모든 시약은 Sigma-Aldrich사(St. Louis, MO, USA)의 제 품을 사용하였다.

\section{증숙도라지 제조}

도라지 증숙 방법은 일반 증숙(steaming), 가압 증숙(autoclave steaming, AS)으로 구분하여, 일반 증숙은 $4 \mathrm{~mm}$ 두께 로 슬라이스한 도라지 $300 \mathrm{~g}$ 을 가정용 스팀솥(Chefline, Bucheon, Korea)를 이용하여 $95^{\circ} \mathrm{C}$ 에서 3 시간 증숙처리하였 으며, 가압 증숙(AS)은 autoclave(DF-100A, DOORI Scientific Co., Bucheon, Korea)를 이용하여 $121^{\circ} \mathrm{C}$ 에서 15 분 동안 증숙 하였다. 증숙처리한 도라지는 열풍건조기(OF-22GW, Jeiotec., Daejeon, Korea)를 이용하여 $50^{\circ} \mathrm{C}$ 에서 12 시간 건조하여 일 반 증숙 및 1차 증숙 도라지(AS1)를 제조하였다. 2차 증숙 도라지(AS2)는 1 차와 같은 방법으로 증숙한 뒤 $50^{\circ} \mathrm{C}$ 에서 8 시간 건조하여 제조하였으며, 3차 증숙(AS3)은 2차 증숙 처 리조건과 동일하게 $121^{\circ} \mathrm{C}$ 에서 15 분 동안 증숙 후 $50^{\circ} \mathrm{C}$ 에서 8 시간 건조하여 처리하였고, 대조구는 증숙 처리를 하지 않 고 $50^{\circ} \mathrm{C}$ 에서 12 시간 건조 처리한 뒤에 시료로 사용하였다.

\section{에탄올 추출물 제조}

도라지를 분쇄기(A11 basic analytical mill, IKA ${ }^{\circledR}$, Staufen, Germany)를 이용하여 분쇄한 후 20 mesh를 통과한 분말 20 $\mathrm{g}$ 을 $70 \%$ ethanol로 각각 $200 \mathrm{~mL}$ 씩 넣고 $70^{\circ} \mathrm{C}$ 에서 2시간씩 2 회 추출하고, 추출물은 Whatman No.1 여과지로 여과 후 감 압농축기(rotary vacuum evaporator N-N series, Eyela, Tokyo, Japan)로 농축한 후에 동결건조(FD SFDSM12, Samwon, Seoul, Korea)하여 분말을 제조하였으며, $-50^{\circ} \mathrm{C}$ 에 저장하면서 실험에 사용하였다.

\section{수분함량, $\mathrm{pH}$ 및 가용성 고형분 측정}

수분함량은 시료 $2 \mathrm{~g}$ 을 칭량하여 적외선 수분측정기(HE53, Halogen Moisture Analyzer, Mettler-Toledo, Zurich, Switzerland)를 사용하여 측정하였다. $\mathrm{pH}$ 는 증숙 및 건조한 도라 지를 분쇄한 시료의 에탄올 추출물을 취하여 $\mathrm{pH}$ meter (ToledoGmbh HG53, Greifensee, Switzerland)로 측정하였으 며, 가용성 고형분 함량은 굴절 당도계(N1, Atago, Tokyo, Japan)로 측정하여 ${ }^{\circ} \mathrm{Brix}$ 표기하였다.

\section{색도 및 갈변도 측정}

증숙 처리에 따른 도라지 색도를 측정하기 위해 건조한 후 분쇄하여 $20 \mathrm{mesh}$ 를 통과시킨 분말을 색차계(Chromameter CR-200, Minolta, Tokyo, Japan)로 측정하였으며, L(lightness), $\mathrm{a}$ (redness) 및 b(yellowness)를 측정하였다. 갈변도는 시료의 에탄올 추출물을 spectrophotometer(UV1601, Shimadzu, Kyoto, Japan)를 사용하여 $420 \mathrm{~nm}$ 에서 흡광도를 측정하였 다. 


\section{총당 및 환원당 함량 측정}

총당 함량은 phenol-sulfate acid법(1994)에 따라 측정하였 다. 즉, 시료 $1 \mathrm{~mL}$ 에 $5 \%$ phenol $1 \mathrm{~mL}$ 와 sulfuric acid $5 \mathrm{~mL}$ 를 가하여 발색시킨 다음 20 분간 방치 후 spectrophotometer (UV1601, Shimadzu)를 이용하여 $470 \mathrm{~nm}$ 에서 흡광도를 측 정하였다. 환원당은 dinitrosalicylic acid(DNS)법(1959)에 의 해 측정하였다. 열수추출 시료용액 $1 \mathrm{~mL}$ 에 DNS 시약 $1 \mathrm{~mL}$ 를 혼합한 뒤 끓는 물에서 15 분 동안 반응시킨 후, 방냉한 것을 spectrophotometer(UV1601, Shimadzu)를 이용하여 $570 \mathrm{~nm}$ 에서 흡광도를 측정하였다. 총당 및 환원당의 정량은 glucose(Sigma-Aldrich Co.)를 표준품으로 한 검량선을 작성 하여 실시하였다.

\section{조사포닌 함량 측정}

조사포닌 함량은 Lee 등(2013)의 연구에서 이용한 $n$-butanol 추출법에 따라 정량하였다. 증숙 처리를 하지 않은 도라지와 증숙 처리한 도라지의 건조분말 $2.5 \mathrm{~g}$ 에 $80 \%$ methanol 25 $\mathrm{mL}$ 를 가해 $70^{\circ} \mathrm{C}$ 에서 1 시간 동안 추출한 다음 여과(Whatman No.2)하였다. 이러한 추출과정을 2회 반복 실시하여 얻어진 추출물을 $50^{\circ} \mathrm{C}$ 에서 감압 농축한 후, 증류수 $25 \mathrm{~mL}$ 를 가하고 diethy lether $25 \mathrm{~mL}$ 로 2회 반복 추출하여 지용성 성분을 제 거하였다. 이후 수포화 $n$-butanol $25 \mathrm{~mL}$ 를 가하여 3 회 반복 추출한 후, 농축 플라스크에 회수하여 감압 농축하였으며, 10 $5^{\circ} \mathrm{C}$ 에서 항량을 구하여 아래 식으로 조사포닌 함량을 계산하 였다.

$$
\begin{aligned}
& \text { 조사포닌 }(\mathrm{mg} \%)= \\
& \frac{\text { 건조 후 수기의 무게 }(\mathrm{mg})-\text { 수기의 무게 }(\mathrm{mg})}{\text { 시료 }(\mathrm{g})} \times 100
\end{aligned}
$$

\section{사포닌 함량 측정}

사포닌 함량 분석은 Kim 등(2016)의 연구에서 이용한 방 법을 참고하였다. 사용된 HPLC는 Waters e2695(Waters Co., Miliford, MA, USA)를 이용하여 측정하였으며, column은 $\mathrm{C}_{18}(4.6 \times 250 \mathrm{~mm}, 5 \mu \mathrm{m}$, Waters co.) column을 사용하였다. 이동상은 water, acetonitrile를 사용하였으며, acetonitrile 비 율을 $0 \min (18 \%)$ - $22 \min (18 \%)$ - $32 \min (30 \%)$ - $60 \min$ $(50 \%)$ 로 순차적으로 조절하였다. Column 온도는 $35^{\circ} \mathrm{C}$ 로 유지 하였고, injection volume은 $10 \mu \mathrm{L}$, 유속은 $1 \mathrm{~mL} / \mathrm{min}$ 로 하였 다. 검출기는 UV/Vis detector (Waters 2489, Waters Co.)로 $203 \mathrm{~nm}$ 에서 측정하였다.

사포닌 추출방법은 Park 등(2000)의 방법에 준하여 도라지 $5 \mathrm{~g}$ 을 $70 \%$ 에탄올 $50 \mathrm{~mL}$ 에 혼합하여 $45^{\circ} \mathrm{C}$ 항온수조에서 2 시간 진탕 후, $4,000 \mathrm{rpm}$ 에서 15 분 원심분리하여 상등액 추
출을 2회 반복하고, 이것을 감압 농축하여 $10 \mathrm{mg}$ 씩 취하여 HPLC-grade 증류수 $1 \mathrm{~mL}$ 에 녹인 후 $0.45 \mu \mathrm{m}$ syringe filter (Advantec, Tokyo, Japan)로 여과하여 사용하였다. 사포닌 표 준시료는 한국한방진흥원 천연물 물질은행(Natural Substance Bank, Korean Promotion Institute for Traditional Medicine Industry, Gyeongsan, Korea)으로부터 분양받은 platycodin D3, deapioplatycodin $\mathrm{D}$, platycoside $\mathrm{E}$ 와 platycodin $\mathrm{D}$ (Sigma-Aldrich Co.)를 각각 $1 \mathrm{mg}$ 씩 취하여 HPLC-grade 증 류수 $10 \mathrm{~mL}$ 에 녹여 HPLC용 표준 사포닌 용액을 조제하여, 표준품을 각각 $12.5,25,50,100 \mu \mathrm{g} / \mathrm{mL}$ 로 조절하여 표준액 을 만들었다. 각 사포닌 표준액 $10 \mu \mathrm{L}$ 를 취하여 $\mathrm{HPLC}$ 로 검 량하고, 작성한 검량선으로부터 환산하였다.

\section{총폴리페놀 및 총플라보노이드 함량 측정}

총폴리페놀 함량은 Dewanto 등(2002)의 방법에 따라 시료 $100 \mu \mathrm{L}$ 에 $2 \%$ sodium carbonate $2 \mathrm{~mL}$ 와 $50 \%$ FolinCiacalteu's reagent $100 \mu \mathrm{L}$ 를 가한 후 $720 \mathrm{~nm}$ 에서 흡광도를 측정하였으며, gallic acid(Sigma-Aldrich Co.)의 검량선에 의 하여 함량을 산출하였다. 총플라보노이드 함량은 Abdel과 Hameed(2009)의 방법에 따라 시료 $100 \mu \mathrm{L}$ 에 $5 \%$ sodium nitrite $0.15 \mathrm{~mL}$ 를 가한 후 $25^{\circ} \mathrm{C}$ 에서 6 분간 방치한 다음 $10 \%$ aluminium choloride $0.3 \mathrm{~mL}$ 를 가하여 $25^{\circ} \mathrm{C}$ 에서 5 분간 방 치하였다. 다음 $1 \mathrm{~N}$ sodium hydroxide $1 \mathrm{~mL}$ 를 가하고 vortex 상에서 가한 후 $510 \mathrm{~nm}$ 에서 흡광도를 측정하였으며, rutin hydrate(Acros-Organics, Morris Plains, NJ, USA)의 검 량선에 의하여 함량을 산출하였다.

\section{$\mathrm{DPPH}$ 라디칼 소거활성 측정}

Blois(1958)의 방법에 따라 시료 $0.2 \mathrm{~mL}$ 에 $0.4 \mathrm{mM}$ DPPH(1,1-diphenyl-2-picryl-hydrazyl) 용액 $0.8 \mathrm{~mL}$ 를 가하 여 10 분간 방치한 다음 $525 \mathrm{~nm}$ 에서 흡광도를 측정하였으며, 계산식, electron donating ability $(\%)=100-[(\mathrm{OD}$ of sample $/ \mathrm{OD}$ of control) $\times 100]$ 에 의하여 활성도를 산출하였다.

\section{$\mathrm{ABTS}^{+}$라디칼 소거활성 측정}

$\mathrm{Re}$ 등(1999)의 방법에 따라 $7.4 \mathrm{mM} \mathrm{ABTS} \mathrm{2,2'-azino-bis}$ (3-ethylbenzothiazoline-6-sulfonic acid)와 $2.6 \mathrm{mM}$ potassium persulfate를 혼합하여 실온암소에서 24시간 동안 방 치하여 radical을 형성시킨 다음 실험 직전에 ABTS 용액을 $732 \mathrm{~nm}$ 에서 흡광도가 $0.700 \pm 0.030$ 이 되도록 phosphate buffer saline(PBS, pH 7.4)로 희석하여 사용하였다. 희석된 용액 $950 \mu \mathrm{L}$ 에 시료액 $50 \mu \mathrm{L}$ 를 가하여 암소에서 10 분간 반응시킨 후 $732 \mathrm{~nm}$ 에서 흡광도를 측정하였으며, 계산식, $\mathrm{ABTS}$ radical scavenging ability $(\%)=100-[(\mathrm{OD}$ of sample $/ \mathrm{OD}$ 
of control) $\times 100]$ 에 의하여 활성을 산출하였다.

\section{통계처리}

모든 실험은 3 회 반복으로 행하여 평균치와 표준편차로 나 타내었고, 유의성 검증은 IBM SPSS Statistics 19(SPSS Inc., Chicago, IL, USA) program을 이용하여 $\mathrm{p}<0.05$ 수준으로 분 산분석과 Duncan's multiple range test를 행하였다.

\section{결과 및 고찰}

\section{수분함량, $\mathrm{pH}$ 및 가용성 고형분 함량}

증숙 처리에 따른 도라지의 수분함량, $\mathrm{pH}$ 및 가용성 고형 분은 Table 1과 같다. 수분함량은 증숙 처리를 하지 않은 대 조구에서 $7.08 \%$ 로 가장 높게 나타났으며, 일반 증숙보다 가 압 증숙 처리구에서 수분함량이 더 낮게 나타났다. 또한, 증 숙 횟수가 증가할수록 감소하는 경향을 나타내었는데, 이러 한 경향은 $50^{\circ} \mathrm{C}$ 에서 건조가 반복됨에 따라 나타난 결과로 판 단된다. 이는 증건 횟수에 따른 우엉의 연구(Lee 등, 2015)에 서도 증건 횟수가 증가할수록 수분함량이 감소하였다는 보고 와 유사하였다. $\mathrm{pH}$ 도 수분함량과 같이 가압 증숙 처리구에서 더 낮게 나타났으며, 증숙 횟수가 증가할수록 감소하는 경향 을 나타내었다. 이러한 결과는 Aida 등(2007)의 연구에서 고 온의 열처리로 인하여 sucrose가 단당류인 fructose로 분해되 고, 분해된 fructose가 $\mathrm{HMF}$, furfural 및 5-methyl furfural 등 과 유기산으로 분해되어 $\mathrm{pH}$ 가 감소하였다고 보고하였다. 또 는 열처리 시 환원당인 aldohexose의 aldehyde기가 산화되어 생성된 carbonyl기의 증가로 인해 $\mathrm{pH}$ 가 감소한다고 보고하 였다(Kim 등, 2012). 가용성 고형분은 일반 증숙 처리구에서 $22.77^{\circ} \mathrm{Brix}$ 로 가장 높게 나타났으며, 시료 간 큰 차이는 나 타나지 않았다.
Table 1. Moisture content, pH and soluble solid content of Platycodon grandiflorums depending on steaming methods and repeated steaming process

\begin{tabular}{cccc}
\hline Sample $^{1)}$ & $\begin{array}{c}\text { Moisture content } \\
(\%)\end{array}$ & $\mathrm{pH}$ & $\begin{array}{c}\text { Soluble solids } \\
\left({ }^{\circ} \text { Brix }\right)\end{array}$ \\
\hline Control & $7.08 \pm 0.20^{\mathrm{a} 2)}$ & $5.69 \pm 0.01^{\mathrm{a}}$ & $21.57 \pm 0.06^{\mathrm{d}}$ \\
Steaming & $6.92 \pm 0.19^{\mathrm{b}}$ & $5.49 \pm 0.01^{\mathrm{b}}$ & $22.77 \pm 0.06^{\mathrm{a}}$ \\
AS1 & $5.89 \pm 0.36^{\mathrm{c}}$ & $5.49 \pm 0.02^{\mathrm{b}}$ & $22.20 \pm 0.10^{\mathrm{b}}$ \\
AS2 & $4.93 \pm 0.54^{\mathrm{d}}$ & $5.03 \pm 0.01^{\mathrm{c}}$ & $22.40 \pm 0^{\mathrm{b}}$ \\
AS3 & $5.96 \pm 0.35^{\mathrm{c}}$ & $4.90 \pm 0.01^{\mathrm{d}}$ & $22.43 \pm 0.06^{\mathrm{b}}$ \\
\hline
\end{tabular}

${ }^{1)}$ Control, not-steamed Platycodon grandiflorum; Steaming, steamed at 95 and dried Platycodon grandiflorum; AS1, autoclave steamed and dried Platycodon grandiflorum by one time; AS2, autoclave steamed and dried Platycodon grandiflorum by two times; AS3, autoclave steamed and dried Platycodon grandiflorum by three times.

${ }^{2)}$ Values are mean \pm SD of triplicate determinations. Different superscripts within a column indicate significant differences $(\mathrm{p}<0.05)$.

\section{색도 및 갈변도}

증숙 방법을 달리한 도라지 분말의 색도 및 갈색도는 Table 2 와 같다. 식품의 색은 가공 시 물리적, 화학적 요인에 의해 변화하여 생리활성 물질의 함량 및 항산화 활성과 연관이 있을 뿐만 아니라, 관능적 특성에도 영향을 미친다(Pellegrini 등, 2010). 밝기를 나타내는 L값은 증숙 처리를 하지 않은 대 조구에서 68.75로 가장 높게 나타났으며, 가압 증숙 처리구 에서 횟수가 증가할수록 감소하는 경향을 나타내었다. 적색 도를 나타내는 $\mathrm{a}$ 값은 증숙 처리구에서 높게 나타났으며, 횟 수가 증가할수록 유의적으로 높게 나타났다. 황색도를 나타 내는 b값은 일반 증숙 처리구에서 20.53으로 가장 높게 나타 났으며, 가압 증숙 처리구에선 횟수가 증가할수록 감소하는 경향을 나타내었다. 이는 Kim 등(2016)의 연구에서 홍삼의 고온고압 처리 시간이 길어질수록 L값이 감소하고, 30 분 이

Table 2. Color values of Platycodon grandiflorums depending on steaming methods and repeated steaming process

\begin{tabular}{|c|c|c|c|c|}
\hline \multirow{2}{*}{ Sample ${ }^{1)}$} & \multicolumn{3}{|c|}{ Color value } & \multirow{2}{*}{$\begin{array}{l}\text { Browning index } \\
\text { (abs at } 420 \mathrm{~nm})\end{array}$} \\
\hline & $\begin{array}{l}\text { Lightness } \\
\left(\mathrm{L}^{*}\right)\end{array}$ & $\begin{array}{l}\text { Redness } \\
\left(\mathrm{a}^{*}\right)\end{array}$ & $\begin{array}{l}\text { Yellowness } \\
\left(\mathrm{b}^{*}\right)\end{array}$ & \\
\hline Control & $68.75 \pm 0.02^{\mathrm{a} 2)}$ & $-0.36 \pm 0.05^{\mathrm{e}}$ & $18.45 \pm 0.29^{c}$ & $0.19 \pm 0^{\mathrm{e}}$ \\
\hline Steaming & $57.16 \pm 0.35^{\mathrm{c}}$ & $3.31 \pm 0.12^{\mathrm{c}}$ & $20.53 \pm 0.15^{\mathrm{a}}$ & $0.38 \pm 0.01^{\mathrm{d}}$ \\
\hline AS1 & $60.68 \pm 0.02^{\mathrm{b}}$ & $2.74 \pm 0.06^{\mathrm{d}}$ & $20.37 \pm 0.20^{\mathrm{ab}}$ & $0.50 \pm 0^{\mathrm{c}}$ \\
\hline AS2 & $50.88 \pm 0.17^{\mathrm{d}}$ & $6.00 \pm 0.03^{\mathrm{b}}$ & $19.77 \pm 0.42^{\mathrm{b}}$ & $2.15 \pm 0.01^{\mathrm{b}}$ \\
\hline AS3 & $42.01 \pm 0.16^{\mathrm{e}}$ & $6.07 \pm 0.03^{\mathrm{a}}$ & $12.86 \pm 0.46^{\mathrm{d}}$ & $2.44 \pm 0.05^{\mathrm{a}}$ \\
\hline
\end{tabular}

\footnotetext{
${ }^{1)}$ Control, not-steamed Platycodon grandiflorum; Steaming, steamed at $95^{\circ} \mathrm{C}$ and dried Platycodon grandiflorum; AS1, autoclave steamed and dried Platycodon grandiflorum by one time; AS2, autoclave steamed and dried Platycodon grandiflorum by two times; AS3, autoclave steamed and dried Platycodon grandiflorum by three times.

${ }^{2)}$ Values are mean $\pm \mathrm{SD}$ of triplicate determinations. Different superscripts within a column indicate significant differences $(\mathrm{p}<0.05)$.
} 
상 증자처리 시 $\mathrm{b}$ 값이 감소하는 결과와 일치하였다. Lee 등 (2015)의 증건 횟수에 따른 우엉의 품질특성 연구에서 증건 우엉의 a값은 증건처리를 하지 않은 생 우엉보다 유의적으로 높게 나타났다.

갈변도는 증숙 횟수에 따라 높아지는 경향을 나타내었으 며, 특히 AS2에서 a값과 갈변도가 유의적으로 증가하였다. 이는 Ryu 등(2003)의 연구에서 갈변도와 명도는 역비례하는 관계이며, Maillard 갈변반응의 초기과정 중 명도의 감소는 황색도도 기여하지만 중반기 이후의 갈변현상은 적색도 위주 임을 입증하여 본 연구 결과와 유사하였다. 갈변은 식품을 가 공, 저장하는 동안 그 색깔이 점차 갈색으로 변하는 것으로, 식품의 품질 및 기능성에 영향을 미친다고 보고된다(Mathew 와 Parpia, 1971). 이는 열에 의해 시료 자체 내에 당 성분과 기타 성분과의 화학적 반응으로 색상 변화에 영향을 미치는 것으로 생각되며, 이러한 반응은 Maillard 반응에 의한 갈색 물질인 멜라노이딘을 형성하였기 때문이라고 판단된다(Kim 등, 2013).

\section{총당 및 환원당 함량}

증숙 처리 방법에 따른 도라지의 총당 및 환원당 함량은 Table 3 과 같다. 총당 함량은 가압 증숙 처리구에서 증숙 횟 수가 증가할수록 총당 함량이 증가하였으며, 가압 증숙 처리 를 한 $\mathrm{AS} 3$ 에서 급격히 증가하는 것을 확인하였다. 총당 함량 은 AS3 > Steaming > AS2 > AS1 > Control 순으로 나타나, 가압처리보다 가열시간에 의한 영향을 더 많이 받는 것으로 판단된다.

환원당 함량은 증숙 처리한 시료에서 증숙 처리를 하지 않 은 대조구보다 높게 나타났으며, 가압 증숙 횟수가 증가함에

Table 3. Total sugar and reducing sugar contents of Platycodon grandiflorums depending on steaming methods and repeated steaming process

(g/g, d.b.)

\begin{tabular}{ccc}
\hline Sample $^{1)}$ & Total sugar content & $\begin{array}{c}\text { Reducing sugar } \\
\text { content }\end{array}$ \\
\hline Control & $0.429 \pm 0.003^{\mathrm{d} 2)}$ & $0.088 \pm 0.001^{\mathrm{e}}$ \\
Steaming & $0.478 \pm 0.007^{\mathrm{b}}$ & $0.125 \pm 0.002^{\mathrm{c}}$ \\
AS1 & $0.444 \pm 0.002^{\mathrm{c}}$ & $0.122 \pm 0.002^{\mathrm{d}}$ \\
AS2 & $0.449 \pm 0.002^{\mathrm{c}}$ & $0.154 \pm 0.002^{\mathrm{b}}$ \\
AS3 & $0.514 \pm 0.009^{\mathrm{a}}$ & $0.186 \pm 0.001^{\mathrm{a}}$ \\
\hline
\end{tabular}

${ }^{1)}$ Control, not-steamed Platycodon grandiflorum; Steaming, steamed at $95^{\circ} \mathrm{C}$ and dried Platycodon grandiflorum; AS1, autoclave steamed and dried Platycodon grandiflorum by one time; AS2, autoclave steamed and dried Platycodon grandiflorum by two times; AS3, autoclave steamed and dried Platycodon grandiflorum by three times.

${ }^{2)}$ Values are mean \pm SD of triplicate determinations. Different superscripts within a column indicate significant differences $(p<0.05)$.
따라 유의적으로 증가하는 경향을 나타내었다. 이는 도라지 에 함유되어 있었던 비환원당이 가열 및 가압 처리에 의해 분해되어 단당류 및 올리고당이 생성된 결과로 판단된다. 증 건횟수에 따른 우엉의 품질특성 연구(Lee 등, 2015)에서도 3 회 증건 우엉에서 환원당 함량이 최대치에 도달하였다는 연 구 결과와 일치하였다. 또한, Lee 등(2013)의 흑도라지 연구 에서 유리당 함량을 분석한 결과, 생도라지에서 sucrose 함량 이 가장 높았으나, 흑도라지에서는 sucrose 함량이 검출되지 않고 glucose와 fructose가 매우 높은 함량을 나타내어 sucrose 가 단당류인 fructose와 glucose로 분해되었기 때문으로 판단 된다고 보고하였다.

\section{조사포닌 함량}

사포닌은 주로 인삼의 유효성분으로 알려져 있으며, 최근 증숙 과정을 거친 홍삼, 흑삼에서 $\operatorname{Rg} 3$ 과 같은 활성이 좋은 진세노사이드가 증가한다고 보고되고 있다(Hong 등, 2007). 하지만 도라지에서는 platycoside라 칭해지는 사포닌을 함유 하고 있으며, triterpene계 사포닌으로 17종의 사포닌이 존재 한다. 이러한 사포닌은 동물 실험에서 진해, 거담작용, 중추 신경 억제작용, 혈압 및 혈당강하 작용, 콜레스테롤 개선작 용, 항산화 및 항암 효과 등이 있는 것으로 알려져 있다(Jang 등, 2011).

증숙 처리에 따른 도라지의 조사포닌 함량은 Table 4 와 같 다. 증숙 처리를 한 도라지에서 모두 대조구보다 높은 조사포 닌 함량을 나타내었다. $\mathrm{AS} 3$ 에서 $37.62 \mathrm{mg} / \mathrm{g}$ 로 가장 높게 나 타났으며, 가압 증숙 횟수가 증가할수록 증가하는 경향을 나 타내었다. 이는 가열 및 가압에 의하여 세포벽과 분자 구조가 파괴됨에 따라 조직이 연화되어 사포닌 추출 효율이 증가하 고, 배당체 형태로 존재하는 사포닌의 aglycon과 당의 결합 이 분해되어 사포닌 함량이 증가한 것으로 판단된다(Park, 2009). Lee 등(2013)의 연구에서도 생도라지와 증숙 가공한 흑도라지의 조사포닌 함량이 2 배 가까이 증가하였다고 보고 한 바 있으며, 열처리에 따른 일반도라지와 으뜸도라지의 품 질특성 연구(Song 등, 2018)에서도 열처리 온도가 증가함에 따라 조사포닌 함량이 증가하였다는 결과와 유사하였다. 따 라서 가압 증숙 처리를 통해 가압 및 가열에 의하여 높은 사 포닌 함량 및 유용성분 추출이 용이할 것으로 판단된다.

\section{증숙처리에 따른 사포닌 함량}

Platycoside류 사포닌 함량은 Table 4와 같이 증숙 처리를 하지 않은 대조구에서 모든 증숙 처리구보다 높게 나타났다. platycodin $\mathrm{D}(819.04 \mathrm{mg} / 100 \mathrm{~g})>$ platycoside $\mathrm{E}(337.48$ $\mathrm{mg} / 100 \mathrm{~g})>$ deapioplatycodin $\mathrm{D}(240.97 \mathrm{mg} / 100 \mathrm{~g})>$ platycodin $\mathrm{D}_{3}(192.01 \mathrm{mg} / 100 \mathrm{~g})$ 순으로 나타나, 이는 Kim 
Table 4. Platycodin saponins and crude saponin content of Platycodon grandiflorums depending on steaming methods and repeated steaming process

\begin{tabular}{cccccc}
\hline Samples ${ }^{1)}$ & $\begin{array}{c}\text { Crude saponin } \\
\text { content } \\
(\mathrm{mg} / \mathrm{g})\end{array}$ & $\begin{array}{c}\text { Platycoside E } \\
(\mathrm{mg} / 100 \mathrm{~g})\end{array}$ & $\begin{array}{c}\text { Platycodin } \mathrm{D}_{3} \\
(\mathrm{mg} / 100 \mathrm{~g})\end{array}$ & $\begin{array}{c}\text { Deapio } \\
\text { platycodin D } \\
(\mathrm{mg} / 100 \mathrm{~g})\end{array}$ & $\begin{array}{c}\text { Platycodin D } \\
(\mathrm{mg} / 100 \mathrm{~g})\end{array}$ \\
\hline Control & $\left.24.27 \pm 1.17^{\mathrm{d} 2}\right)$ & 337.48 & 192.01 & 240.97 & 819.04 \\
Steaming & $32.61 \pm 0.26^{\mathrm{bc}}$ & 272.84 & 156.45 & 161.27 & 611.55 \\
AS1 & $30.73 \pm 0.99^{\mathrm{c}}$ & 226.30 & 157.58 & 188.79 & 574.60 \\
AS2 & $33.62 \pm 1.10^{\mathrm{b}}$ & 200.24 & 150.23 & 206.42 & 510.71 \\
AS3 & $37.62 \pm 1.59^{\mathrm{a}}$ & 171.62 & 145.2 & 232.04 & 497.22 \\
\hline
\end{tabular}

${ }^{1)}$ Control, not-steamed Platycodon grandiflorum; Steaming, steamed at $95^{\circ} \mathrm{C}$ and dried Platycodon grandiflorum; AS1, autoclave steamed and dried Platycodon grandiflorum by one time; AS2, autoclave steamed and dried Platycodon grandiflorum by two times; AS3, autoclave steamed and dried Platycodon grandiflorum by three times.

${ }^{2)}$ Values are mean \pm SD of triplicate determinations. Different superscripts within a column indicate significant differences $(\mathrm{p}<0.05$ ).

등(2007)의 HPLC를 이용한 도라지 사포닌 분석법 연구에서 platycodin $\mathrm{D}$ 의 함량이 가장 높고, 그 다음으로 platycoside E가 많이 함유되어 있다는 연구 결과와 유사하게 나타났다.

도라지의 platycodin complex 함량은 모두 증숙 처리구에 서 대조구보다 낮게 나왔으나, 조사포닌 함량은 증가한 것으 로 나타나 가압 및 가열 처리에 의하여 큰 분자량의 사포닌이 분해되어 작은 분자량의 사포닌이 생성되는 것으로 사료된 다. 이는 Kim 등(2016)의 흑도라지의 천식 동물모델에 대한 면역조절효과 연구에서도 분자량이 상대적으로 큰 platycodin $\mathrm{D}_{3}$ 의 경우 9 증 9 포를 통하여 $1 / 10$ 로 감소하였고, 분자량이 작 은 polygalacin $\mathrm{D}$ 의 경우 $1 / 1.8$ 로 감소하여 큰 분자량의 사포 닌이 작은 분자량의 사포닌으로 분해되어 조사포닌 함량 증 가에도 영향을 미친다고 보고하여 본 연구 결과와 유사한 경 향을 나타내었다. 도라지의 대표 지표물질인 platycoside E는 상대적으로 분자량이 큰 물질로 증숙 처리에 의하여 감소하 는 경향을 나타내었으며, 가압 증숙 처리 횟수가 증가함에 따 라 감소하여 가열 및 가압에 의해 분해되었다고 판단된다. $\mathrm{NO}$ 생성과 TNF-alpha 분비를 조절하는 platycodin $\mathrm{D}_{3}$ (Wang 등, 2004)는 감소하였으나, 증숙 처리에 의한 큰 차이는 나타 내지 않았다. Platycodin D 역시 증숙 처리에 의하여 감소하 였으며, 이와 반대로 deapioplatycodin $\mathrm{D}$ 의 경우 가압 처리 증숙에서 횟수가 증가함에 따라 증가하였다. 이는 $\mathrm{Ha}$ 등 (2008)의 연구에서 도라지를 $125^{\circ} \mathrm{C}$ 에서 $1,2,3,6$ 및 9시간 증숙 시간이 지남에 따라 deapi 형태의 사포닌이 증가한다는 보고와 일치하였다. 또한, Park 등(2012)의 팽화 처리 도라지 연구에서도 팽화 압력이 증가함에 따라 platycoside 함량과 major platycoside 함량이 감소하였으며, 이는 triterpenoid backbone을 가진 major saponin 3번 탄소에 glycosidic bond 로 결합된 glucose와 28번 탄소에 ester bond에 의해 결합된 arabinose-rhamnose-xylose-apiose가 열과 압력에 의해서 쉽
게 깨지고, 그로 인해 platycodin complex 함량이 감소되는 것으로 추측된다고 보고하였다. 따라서 여러 효능을 가지고 있는 길경 추물의 주성분은 platycodin $\mathrm{D}$ 이며, 이에 결합한 당은 오탄당인 D-apiose로서 platycodins의 생리작용과 밀접 한 관계에 있는 것으로 보고 있으며(Kang 등, 2008), 비당체 를 섭취하였을 때 배당체를 섭취한 것보다 혈중 농도가 더 높다는 연구 결과(Izumi 등, 2000)를 바탕으로 platycodin complex 함량이 감소되었으나, 작은 분자량의 사포닌이 늘어 나 생체이용률이 높아져 체내 흡수가 증가할 것으로 판단된 다. 또한, platycodin은 알려진 약리학적 효능에도 불구하고, 특이한 아린맛과 쓴맛을 가지고 있어(Kang 등, 2008) 증숙 처리를 통하여 관능적으로도 개선할 수 있을 것이라고 사료 된다.

\section{총폴리페놀 및 총플라보노이드 함량}

총폴리페놀 및 총플라보노이드 함량은 Table 5 와 같으며, 모두 가압 증숙 처리 시 유의적으로 증가하는 경향을 나타내 었다. 총폴리페놀 함량은 대조구와 일반 증숙 처리구에서 큰 차이를 나타내지 않았으며, 가압증숙 처리구에서 13.62-34.74 $\mathrm{mg} \mathrm{GAE} / \mathrm{g}$ 으로 반복횟수에 따라 증가하는 경향을 나타내었 다. 또한, 총플라보노이드 함량은 총폴리페놀 함량과 유사한 경향을 나타내었으나, 일반 증숙 처리시 대조구에 비해 감소 하였으며, 가압증숙 처리시 횟수가 증가함에 따라 총 플라보 노이드 함량이 증가하였다. 이는 고온고압 처리한 과채류를 이용한 연구(Kim 등, 2008; Park과 Hong, 2017) 결과에서 처 리 온도가 증가할수록 총 페놀 함량이 증가한다는 결과와 유 사하였다. 또한, 증건 횟수에 따른 우엉의 연구(Lee 등, 2015) 에서도 3,5 회 증건 시료에서 가장 높은 함량을 보였으며, Jin 등(2012)의 연구에서도 인삼을 증가함에 따라 폴리페놀 함량 이 점차 증가하다 감소하였다고 보고하였다. 따라서 결합형 
Table 5. Total polyphenol and total flavonoid contents of Platycodon grandiflorums depending on steaming methods and repeated steaming process

\begin{tabular}{ccc}
\hline Samples ${ }^{1)}$ & $\begin{array}{c}\text { Total polyphenol } \\
\text { contents } \\
\left(\mathrm{mg} \mathrm{GAE}^{2} / \mathrm{g}\right)\end{array}$ & $\begin{array}{c}\text { Total flavonoid } \\
\text { contents } \\
\left(\mathrm{mg} \mathrm{RHE}^{3)} / \mathrm{g}\right)\end{array}$ \\
\hline Control & $10.99 \pm 0.09^{\mathrm{d} 4)}$ & $3.87 \pm 0.24^{\mathrm{d}}$ \\
Steaming & $10.96 \pm 0.23^{\mathrm{d}}$ & $2.91 \pm 0.21^{\mathrm{e}}$ \\
AS1 & $13.62 \pm 0.26^{\mathrm{c}}$ & $5.79 \pm 0.21^{\mathrm{c}}$ \\
AS2 & $26.86 \pm 0.39^{\mathrm{b}}$ & $9.23 \pm 0.12^{\mathrm{b}}$ \\
AS3 & $34.74 \pm 0.74^{\mathrm{a}}$ & $12.53 \pm 0.12^{\mathrm{a}}$ \\
\hline
\end{tabular}

${ }^{1)}$ Control, not-steamed Platycodon grandiflorum; Steaming, steamed at $95^{\circ} \mathrm{C}$ and dried Platycodon grandiflorum; AS1, autoclave steamed and dried Platycodon grandiflorum by one time; AS2, autoclave steamed and dried Platycodon grandiflorum by two times; AS3, autoclave steamed and dried Platycodon grandiflorum by three times. ${ }^{2)} \mathrm{GAE}$, gallic acid equivalent.

${ }^{3)}$ RHE, rutin hydrate equivalent.

${ }^{4)}$ Values are mean $\pm \mathrm{SD}$ of triplicate determinations. Different superscripts within a column indicate significant differences $(\mathrm{p}<0.05)$.

폴리페놀이 고온고압 처리에 의해 유리형으로, 고분자에서 저분자 페놀화합물로 전환되어 총페놀 함량이 증가한 것으로 판단된다(Choi 등, 2006).

\section{DPPH 및 ABTS 라디칼 소거활성}

천연물 중 라디칼을 환원시키는 능력이 크면 항산화 활성 이 크다고 기대할 수 있으며(Kim 등, 2011), 시료의 특성에 따라 $\mathrm{DPPH}$ 라디칼과 $\mathrm{ABTS}$ 라디칼과의 결합 정도가 다를 수 있다고 보고된다(Kim 등, 2011). DPPH 및 ABTS 라디칼 소거활성은 Fig. 1,2 와 같이 모두 가압 증숙 처리구에서 유 의적으로 증가하였으며, $\mathrm{AS} 31.5 \mathrm{mg} / \mathrm{mL}$ 농도에서 각각 $31.92 \%, 49.97 \%$ 로 가장 높은 라디칼 소거활성을 가지는 것 으로 나타났다. 이는 증숙 횟수가 증가함에 따라 도라지에 존 재하는 활성성분들의 추출수율을 향상시키고, 증숙처리에 의 해 증가된 폴리페놀과 플라보노이드에 의해 항산화력이 증대 되었다고 사료된다. $\mathrm{Kim}$ 등(2011)의 흑삼의 증포횟수가 증 가함에 따라 $50 \%$ 에탄올로 추출한 추출물의 갈색도가 크게 증가하고, 비례적으로 $\mathrm{DPPH}$, hydroxy 및 ABTS 라디칼 소 거능 또한 증가하여 증포횟수가 증가함에 따라 항산화성이 크게 증가한다고 보고된다. 또한, Song 등(2012)의 연구에서 증숙 공정 중에 생성된 갈변물질이 자유라디칼을 소거시켜 항산화 효능을 향상시켰다는 보고와 일치하였다.

따라서 증숙 과정을 거치는 것이 도라지의 가공적성 및 생 리활성 증진에 도움이 되며, 일반 증숙보다 가압 증숙 공정이 신속하고, 반복된 증숙을 통해 품질 또한 뛰어난 고기능성 도 라지 가공품 개발에 응용 가능한 공정이라고 판단된다.

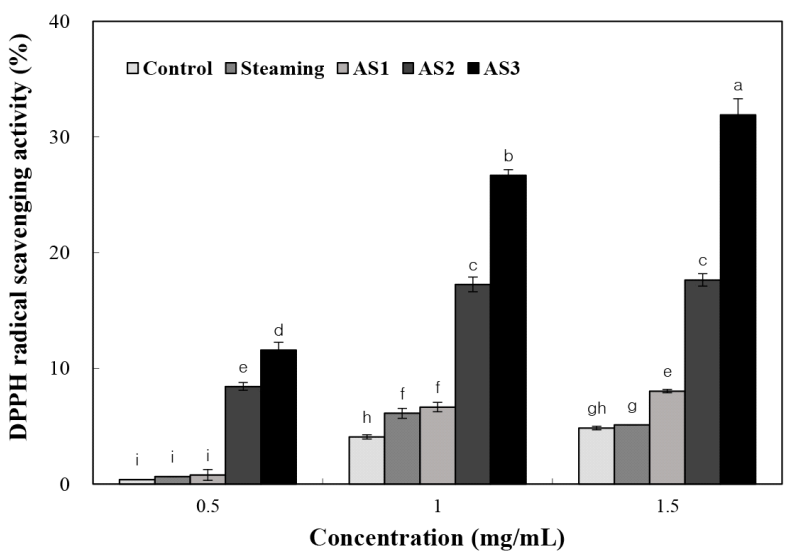

Fig. 1. DPPH radical scavenging activity of Platycodon grandiflorums depending on steaming methods and repeated steaming process.

Control, not-steamed Platycodon grandiflorum; Steaming, steamed at $95^{\circ} \mathrm{C}$ and dried Platycodon grandiflorum; AS1, autoclave steamed and dried Platycodon grandiflorum by one time; AS2, autoclave steamed and dried Platycodon grandiflorum by two times; AS3, autoclave steamed and dried Platycodon grandiflorum by three times. Values are mean $\pm \mathrm{SD}$ of triplicate determinations. Values with different letters on the bar $\left({ }^{\mathrm{a}-\mathrm{i}}\right)$ indicate significant differences $(\mathrm{p}<0.05)$.

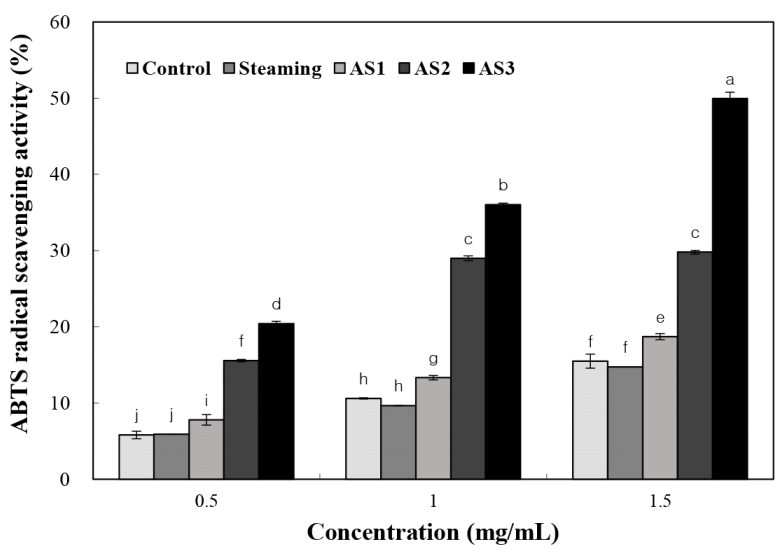

Fig. 2. ABTS radical scavenging activity of Platycodon grandiflorums depending on steaming methods and repeated steaming process.

Control, not-steamed Platycodon grandiflorum; Steaming, steamed at $95^{\circ} \mathrm{C}$ and dried Platycodon grandiflorum; AS1, autoclave steamed and dried Platycodon grandiflorum by one time; AS2, autoclave steamed and dried Platycodon grandiflorum by two times; AS3, autoclave steamed and dried Platycodon grandiflorum by three times. Values are mean $\pm S D$ of triplicate determinations. Values with different letters on the bar $\left({ }^{a-j}\right)$ indicate significant differences $(p<0.05)$.

\section{요 약}

다양한 생리활성을 지닌 도라지의 가공적 활용성 및 기능 성 증진을 위한 목적으로 증숙 처리에 따른 도라지의 이화학 적 특성과 생리활성 변화에 미치는 영향에 대하여 조사하였 
다. 증숙처리는 일반 증숙은 $95^{\circ} \mathrm{C}$ 에서 3 시간, 가압 증숙은 $121^{\circ} \mathrm{C}$ 에서 15 분간 처리한 후 $50^{\circ} \mathrm{C}$ 에서 12 시간 건조하였으 며, 이를 3 회 반복처리하였다. 수분함량은 증숙 횟수가 증가 할수록 감소하였으며, $\mathrm{pH}$ 또한 감소하는 경향을 나타내었다. 가용성 고형분은 일반 증숙에서 가장 높게 나타났으나, 유의 적인 차이는 보이지 않았다. 색도 중 밝기를 나타내는 L값과 황색도를 나타내는 $b$ 값은 가압 증숙 처리구에서 횟수가 증가 할수록 감소하는 경향을 나타내었으며, 적색도를 나타내는 a 값의 경우 증가하는 경향을 나타내었다. 총당 및 환원당 함량 에서는 $\mathrm{AS} 3$ 에서 각각 $0.514 \mathrm{~g} / \mathrm{g}, 0.186 \mathrm{~g} / \mathrm{g}$ 으로 가장 높게 나타났다. 조사포닌 함량은 $\mathrm{AS} 3>\mathrm{AS} 2>$ Steaming > AS1 $>$ Control 순으로 나타났으며, 모든 증숙 처리구에서 대조구 보다 높은 함량을 나타내었다. Platycodin complex 사포닌 함 량은 모두 대조구에 비해 감소하는 경향을 나타내었다. 총폴 리페놀 및 총플라보노이드 함량은 대조구와 일반 증숙 처리 구보다 가압 증숙 처리구에서 유의적으로 높았으며, 증숙 과 정이 반복됨에 따라 증가하는 경향을 나타내었다. DPPH 및 $\mathrm{ABTS}$ 라디칼 소거활성 또한 가압 증숙 처리에 의하여 증가 하였으며, AS2에서 유의적으로 높아지는 경향을 나타내었 다. 따라서 가압 증숙 처리 방법을 이용하여 도라지를 이용한 가공품 개발 시 공정 시간의 단축과 동시에 생리활성 증진을 기대할 수 있다고 사료된다.

\section{감사의 글}

본 논문은 2020년도 대구가톨릭대학교 교내연구비 지원에 의한 것으로 감사드립니다.

\section{Conflict of interests}

The authors declare no potential conflict of interest.

\section{ORCID}

Jung-Min Kim https://orcid.org/0000-0003-3193-3594

Kwang-Sup Youn https://orcid.org/0000-0001-7451-0554

\section{References}

Abdel-Hameed ESS. Total phenolic contents and free radical scavenging activity of certain Egyptian Ficus species leaf samples. Food Chem, 114, 1271-1277 (2009)

Aida TM, Tajima K, Watanabe M, Saito Y, Kuroda K, Nonaka T, Hattori H, Smith Jr RL, Arai K. Reactions of D-fructose in water at temperatures up to $400^{\circ} \mathrm{C}$ and pressures up to $100 \mathrm{MPa}$. J Supercrit Fluids, 42, 110119 (2007)

Blois MS. Antioxidant determinations by the use of a stable free radical. Nature, 181, 1199-1200 (1958)

Choi Y, Lee SM, Chun J, Lee HB, Lee J. Influence of heat treatment on the antioxidant activities and polyphenolic compounds of shiitake (Lentinus edodes) mushroom. Food Chem, 99, 381-387 (2006)

Dewanto V, Wu X, Adom KK, Liu RH. Thermal processing enhances the nutritional value of tomatoes by increasing total antioxidant activity. J Agric Food Chem, 50, 30103014 (2002)

Ha IJ, Chung JW, Ha YW, Shin EM, Kim YS. Compositional analysis of major saponins and anti-inflammatory activitiy of steam-processed Platycodi radix under pressure. Nat Prod Sci, 14, 274-280 (2008)

Hong HD, Kim YC, Rho J, Kim KT, Lee YC. Changes on physicochemical properties of Panax ginseng C.A. Meyer during repeated steaming process. J Ginseng Res, 31, 222-229 (2007)

Hwang SJ, Kim JW. Effects of roots powder of balloon flowers on general composition and quality characteristics of Sulgidduk. Korean J Food Culture, 22, 77-82 (2007)

Izumi T, Piskula MK, Osawa S, Obata A, Tobe K, Saito M, Kataoka S, Kubota Y, Kikuchi M. Soy isoflavone aglycones are absorbed faster and in higher amounts than their glucosides in humans. J Nutr, 130, 1695-1699 (2000)

Jang JR, Hwang SY, Lim SY. Inhibitory effect of extracts of Platycodon grandiflorum (the ballon flower) on oxidation and nitric oxide production. Korean $\mathrm{J}$ Food Preserv, 18, 65-71 (2011)

Jeong SI, Yu HH. Quality characteristics of Sikhe prepared with the roots powder of Doraji (Platycodon grandiflorum A. DE. Candolle). J Korean Soc Food Sci Nutr, 42, 759-765 (2013)

Jin LJ, Ha JH, Jeong MH, Chung EK, Chung AR, Kim JC, Ahn JH, Lee HY. Enhancement of the antioxidant and anticancer activities of Berberis koreana bark by using a low temperature and high-pressure extraction process. Korean J Food Sci Technol, 41, 284-291 (2009)

Jin Y, Kim YJ, Jeon JN, Wang C, Min JW, Jung SY, Yang 
DC. Changes of ginsenosides and physiochemical properties in ginseng by new 9 repetitive steaming and drying process. Korean J Plant Res, 25, 473-481 (2012)

Kang JH, Ji GU, Wui HJ, Hwang IK. The transformation of saponin Platycodi Radix by Aspergillus niger and anti-oxidation evaluation of the transformed metabolites. Korean J Food Cookery Sci, 24, 729-734 (2008)

Kim E, Jin Y, Kim KT, Lim TG, Jang M, Cho CW, Rhee YK, Hong HD. Effect of high temperature and high pressure on physicochemical properties and antioxidant activity of Korean red ginseng. Korean J Food Nutr, 29, 438-447 (2016)

Kim HG, Kim GW, Oh H, Yoo SY, Kim YO, Oh MS. Influence of roasting on the antioxidant activity of small black soybean (Glycine max L. Merrill). LWT-Food Sci Technol, 44, 992-998 (2011)

Kim HJ, Lee JY, You BR, Kim HR, Choi JE, Nam KY, Moon BD, Kim MR. Antioxidant activities of ethanol extracts from black ginseng prepared by steaming-drying cycles. J Korean Soc Food Sci Nutr, 40, 156-162 (2011)

Kim HY, Woo KS, Hwang IG, Lee YR, Jeong HS. Effects of heat treatments on the antioxidant activities of fruits and vegetables. Korean J Food Sci Technol, 40, 166-170 (2008)

Kim JW, Ha MA, Shin YW. Nine repetitive steamed Platycodon grandiflorum root restores $\mathrm{Th} 1 / \mathrm{Th} 2$ cytokine imbalance in an ovalbumin-induced asthmatic mouse model. J Korean Soc People Plants Environ, 19, 335-344 (2016)

Kim KM, Kim YN, Choi BK, Oh DH. Physiochemical and microbiological changes of the fermented dandelion (Taraxacum officinale) extracts with raw sugar. Korean J Food Preserv, 19, 131-137 (2012)

Kim MY, Lee SH, Jang GY, Kim HY, Woo KS, Hwang IG, Lee J, Jeong HS. Effects of heat treatment on antioxidant activity of hydrolyzed mung beans. Korean J Food Sci Technol, 45, 34-39 (2013)

Kim SH, Jeong MJ. Safety and anticancer effects of Platycodon grandiflorum extracts. J Korean Soc Food Sci Nutr, 44, 516-523 (2015)

Kim SS, Jeong MH, Seo YC, Kim JS, Kim NS, Woon WB, Ahn JH, Hwang B, Park DS, Park SJ, Lee HY. Comparison of antioxidant activities by high pressure extraction of Codonopsis lanceolata from different production areas. Korean J Medicinal Crop Sci, 18, 248-254 (2010)

Lee BJ, Jeon SH, Lee SW, Chun HS, Cho YS. Effect of drying methods on the saponin and mineral contents of Platycodon grandiflorum Radix. Korean J Food Sci Technol, 46, 636-640 (2014)

Lee GY, Son YJ, Jeon YH, Kang HJ, Hwang IK. Changes in the physicochemical properties and sensory characteristics of burdock (Arctium lappa) during repeated steaming and drying procedures. Korean J Food Sci Technol, 47, 336-344 (2015)

Lee SJ, Shin SR, Yoon KY. Physicochemical properties of black Doraji (Platycodon grandiflorum). Korean J Food Sci Technol, 45, 422-427 (2013)

Mathew AG, Parpia HAB. Food browning as a polyphenol reaction. Adv Food Res, 19, 75-145 (1971)

Miller GL. Use of dinitrosalicylic acid reagent for determination of reducing sugar. Anal Chem, 31, 426-428 (1959)

Park HM, Hong JH. Physicochemical properties and protective effects of Corni fructus treated with pressurized-steam against $\mathrm{H}_{2} \mathrm{O}_{2}$-induced cytotoxicity on L132 cells. J Korean Soc Food Sci Nutr, 46, 1061-1070 (2017)

Park IS, Kang EM, Kim NS. High-performance liquid chromatographic analysis of saponin compounds in Bupleurum falcatum. J Chromatogr Soc, 38, 229-233 (2000)

Park JH. Preparation of red Doraji extract and quality properties by extract and aging condition. MS Thesis, Joongbu University, Korea, p 38 (2011)

Park MS, Park DY, Son KH, Koh BK. A study on quality characteristics of Doraji (Platydodon grandiflorum) yanggeng using by different pre-treatment methods and amounts adding levels of Doraji. J East Asian Soc Dietary Life, 19, 78-88 (2009)

Park SJ, Kim AY, Lee HS, Kim BY, Baik MY. Effects of puffing process on the saponin components in Platycodon grandiflorus (jacqin) A.De Candle. Food Eng Prog, 16, 164-171 (2012)

Park SJ, Seong DH, Park DS, Kim SS, Gou J, Ahn JH, Yoon WB, Lee HY. Chemical compositions of fermented Codonopsis lanceolata. J Korean Soc Food Sci Nutr, 38, 396-400 (2009)

Pellegrini N, Chiavaro E, Gardana C, Mazzeo T, Contino D, 
Gallo M, Riso P, Fogliano V, Porrini M. Effect of different cooking methods on color, phytochemical concentration, and antioxidant capacity of raw and frozen Brassica vegetables. J Agric Food Chem, 58, 4310-4321 (2010)

Re R, Pellegrini N, Proteggente A, Pannala A, Yang M, Rice-Evans C. Antioxidant activity applying an improved ABTS radial cation decolorization assay. Free Radical Biol Med, 26, 1231-1237 (1999)

Ryu SY, Roh HJ, Noh BS, Kim SY, Oh DK, Lee WJ, Yoon JR, Kim SS. Effects of various sugars including tagatose and their molar concentrations on the Maillard browning reaction. Korea J Food Sci Technol, 35, 898-904 (2003)

Saha SK, Brewer CF. Determination of the concentrations of oligosaccharides, complex type carbohydrates, and glycoproteins using the phenol-sulfuric acid method. Carbohydr Res, 254, 157-167 (1994)

Song CH, Seo YC, Choi WY, Lee CG, Kim DU, Chung JY, Chung HC, Park DS, Ma CJ, Lee HY. Enhancement of antioxidative activity of Codonopsis lanceolata by stepwise steaming process. Korean J Medicinal Crop Sci, 20, 238-244 (2012)

Song MS, Kim MY, Jang GY, Lee YJ, Li M, Oh H, Lee J, Jeong HS. Changes in quality characteristics in the normal and Etteum Doraji (Platycodon grandiflorum) by heat treatment. J Korean Soc Food Sci Nutr, 47, 462467 (2018)

Wang C, Levis GBS, Lee EB, Levis WR, Lee DW, Kim BS, Park SY, Park E. Platycodin D and $\mathrm{D}_{3}$ isolated from the root of Platycodon grandiflorum modulate the production of nitric oxide and secretion of TNF- $\alpha$ in activated RAW 264.7 cells. Int Immunopharmacol, 4, 1039-1049 (2004)

Yoo DS, Choi YH, Cha MR, Choi CW, Kim MR, Yon GH, Hong KS, Lee BH, Kim EJ, Cho SW, Kim YS, Ryu SY, Kang JS. Variation of saponin content in the decoctions of Platycodi radix (II). Kor J Pharmacogn, 41, 147-152 (2010) 